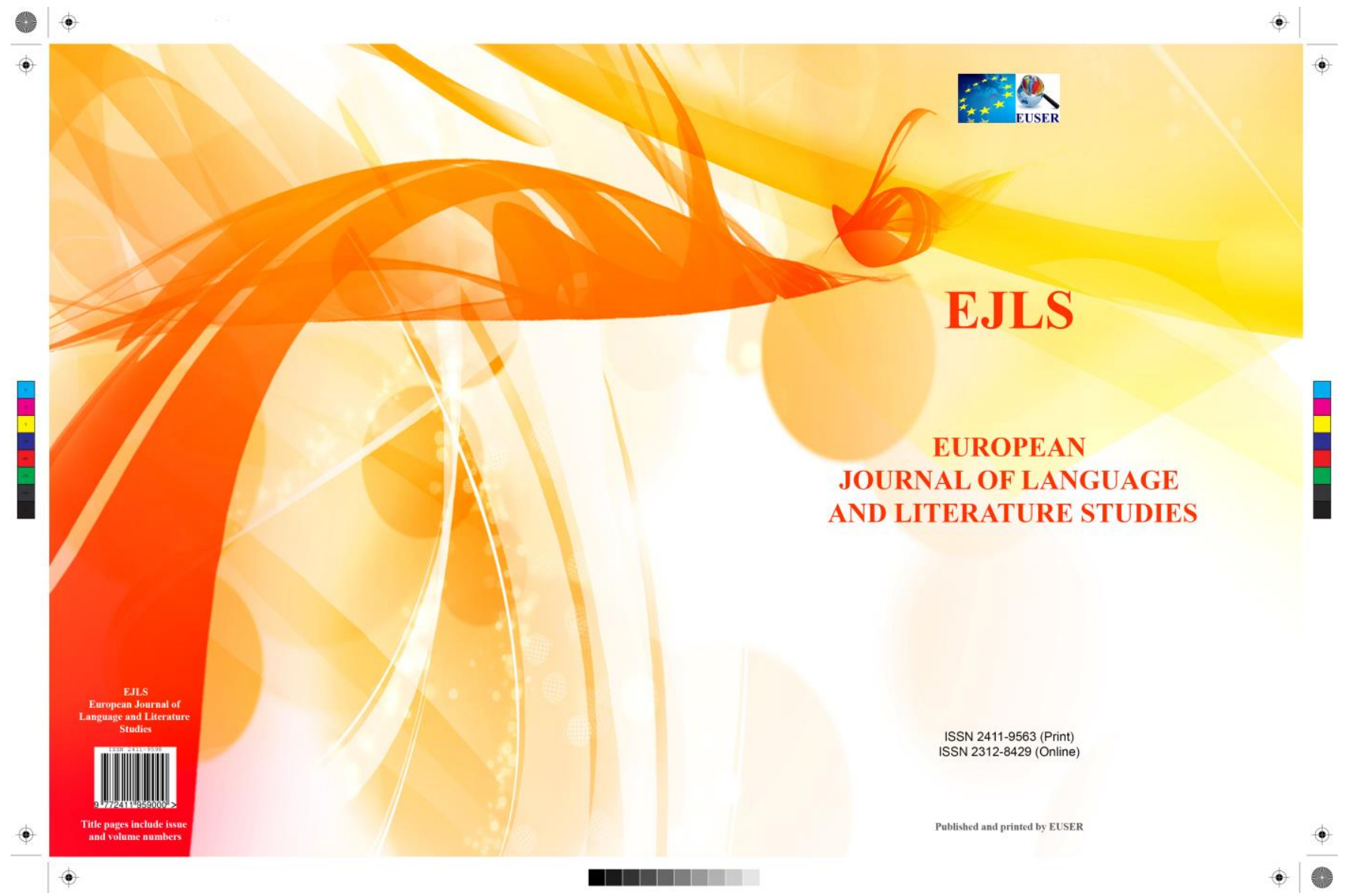




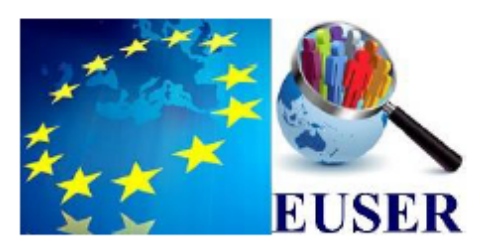

EUROPEAN CENTER FOR SCIENCE EDUCATION AND RESEARCH

\section{EUROPEAN JOURNAL OF LANGUAGE \\ AND LITERATURE STUDIES}

May-August 2015

Volume 2, Nr. 1

ISSN 2411-9598 (Print)

ISSN 2411-4103 (Online) 
EUSER

EUROPEAN CENTER FOR SCIENCE EDUCATION AND RESEARCH

First Published 2015

\section{EUROPEAN JOURNAL OF LANGUAGE \\ AND LITERATURE STUDIES}

May-August 2015

Volume 2, Nr. 1

Every reasonable effort has been made to ensure that the material in this book is true, correct, complete, and appropriate at the time of writing. Nevertheless the publishers, the editors and the authors do not accept responsibility for any omission or error, or for any injury, damage, loss, or financial consequences arising from the use of the book. The views expressed by contributors do not necessarily reflect those of the European Center for Science Education and Research.

Typeset by EUSER

Printed by EUSER

EUROPEAN CENTER FOR SCIENCE EDUCATION AND RESEARCH

May-August 2015

\section{Copyright @ 2015 EUSER}

(c) All rights reserved. No part of this book may be reproduced in any form or by any electronic or mechanical means, including information storage and retrieval systems, without written permission from the publisher or author, except in the case of a reviewer, who may quote brief passages embodied in critical articles or in a review.

European Center for Science Education and Research

Contact: Sheshi Rilinda, Nr. 38, Tirana, Albania. Tel: +355 673374134

Web: http://euser.org, E-Mail: info@euser.org

$$
\text { ISSN 2411-9598 (Print) }
$$

ISSN 2411-4103 (Online)

Key title: European journal of language and literature studies

Abbreviated key title: Eur. j. lang. lit. stud. 
International Advisory Board

Prof. Dr. Mixhait Reci, President lliria College, Pristina-Kosovo

Prof. Dr. Catalin Zamfir, Director, ICCV, Academia Romana

Prof. Dr. Emilian Dobrescu, Academia Romana

Prof Dr. Elena Zamfir, University of West, Timişoara, Romania

Prof Dr. Misu Jan Manolescu, Rector, University of Oradea, Romania

Prof. Dr. Emilian Dobrescu, Institute of Sociology, Academia Romana

Prof. Dr. Mame S. Sutoko, Rector, Widyatama University, Bandung - Indonesia

Prof. Dr. İsmail Hakki Mirici, President, WCCl, Turkiye

Prof. Dr. Ms. Jurate Baranova, Lithuania

Prof. Dr. Rodica Sirbu, Ovidius" University of Constanţa, Faculty of Pharmacy, Romania

Dr. Sandro Knezovic, Seniour Research Fellow, Institute for Development and International Relations, Zagreb, Croatia

Prof. dr. Siebren Miedema, Educational Foundations Department, Faculty of Psychology and Education, VU University, Amsterdam

Slađana Živković, PhD. College of Applied Technical Studies. Serbia

Univ. -Prof. Dr. Matthias Scharer, Innsbruck, Austria

Dr. Sokol Pacukaj, MCSER, Italy

Dr. Ferdinand Gjana, Henae e Plote Beder University, Albania

Dr. Edith Dobre, Romanian Academy 
Editorial Board

Prof. Assoc. Dr. Ahmet Ecirli, Hena e Plote Beder University, Tirana, Albania

Dr. Sokol Pacukaj, PhD, MCSER, Rome, Italy

Dr. Iulian Stanescu, ICCV, Academia Romana

Mihaela loana Danetiu, EUSER, European Center for Science Education and Research

Dr. Irma Shyle, Albania

Dr. Vjollca Hysi (Panajoti), Albania

Assoc. Prof. Dr. Dilek Erduran Avcı, Mehmet Akif Ersoy University, Turkey

Dr. Alicja Grześkowiak, Wrocław University of Economics, Poland

Dr. Mahmut Terci, Beder University, Albania

Dr. Arumugam Raman, Malaysia

Prof. Dr. Ms. Jurate Baranova, Lithuania

Dr. Veton Halim Zejnullahi, Kosovo

Dr. Fatma Demiray, Turkey

Dr. Simona Maria Stanescu, Research Institute for Quality of Life, Romanian Academy, Romania

Assoc. Prof. Dr. Dilek Erduran Avcı, Mehmet Akif Ersoy University, Turkey

Assoc. Prof. Dr. Norsiah Binti Fauzan, Universiti Malaysia Sarawak, Malaysia

Dr. Sc. Rrustem Qehaja, Kosovo

Assoc. Prof. Dr. Bekim Fetaji, South East European University, Albania

Prof. Dr. Rodica Sirbu, Ovidius" University of Constanţa, Faculty of Pharmacy, Romania

Dr. Emin Alp Malkoç, Turkey

Assoc. Prof. Dr. Bahattin Aydinli, Education Faculty, Kastamonu University, Turkey

Dr. Sevim Yılmaz, Pamukkale University Turkiye

Iffet Aksoy Tokgöz, Faculty of Education, Çanakkale Onsekiz Mart University, Turkey

Ticuţa Negreanu-Pîrjol, Ovidius" University of Constanţa, Romania 


\section{Executive Committe Members}

Prof. Assoc. Dr. Ahmet Ecirli,

Hena e Plote Beder University, Tirana, Albania

Dr. Iulian Stanescu,

ICCV, Romanian Academy

Simona Maria Stănescu,

ICCV, Romanian Academy

Mihai Dumitru,

ICCV, Romanian Academy

Mihaela I. Danetiu,

EUSER, European Center for Science Education and Research

Eriselda Vrapi,

EUSER, European Center for Science Education and Research

Dr. Veton Zejnullahi,

European Center for Science Education and Research, Kosovo

Ms. Evzi Hani,

lliria College, Prishtina, Kosovo

Fitore Bekteshi,

lliria College, Prishtina, Kosovo

Blerta Obertinca, International Cooperation Officer, lliria College, Prishtina, Kosovo 
TABLE OF CONTENTS

THE MEANINGS OF PREFIX “OVER”

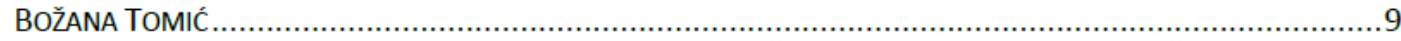

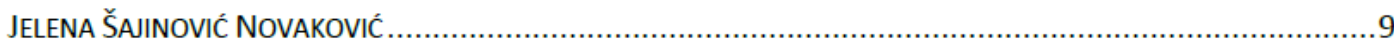

CHALLENGES IN CHILDREN'S LITERATURE TRANSLATION: A THEORETICAL OVERVIEW ...............15

AIDA ALLA, PH.D CAND.

NEGOTIATING BETWEEN THE CONSTANT AND THE CHANGING: BALANCING ACTS IN THE

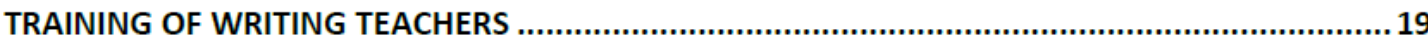

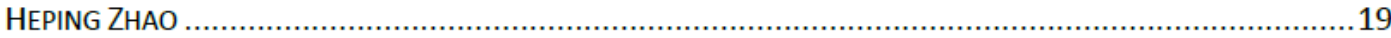

THE VOCATIVE CASE: ROMANIAN VERSUS LATIN ....................................................................26

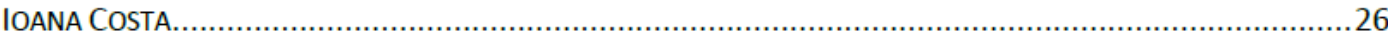

NATIONAL IDENTITY AND THE “GREAT DIVIDE" BETWEEN TWO THEORIES. WHERE DOES THE ALBANIAN NATIONAL IDENTITY TAKE PART ........................................................................... 31

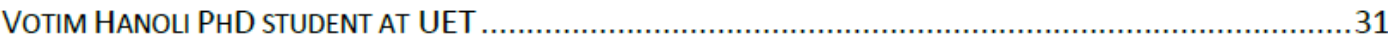

COMPOUND PRONOUNS IN ENGLISH AND ALBANIAN ............................................................. 36

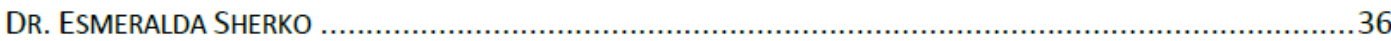

ICT IN FOREIGN LANGUAGE TEACHING AND LEARNING: BENEFITS AND CHALLENGES ...............42 42

MARSIDA DEDJA

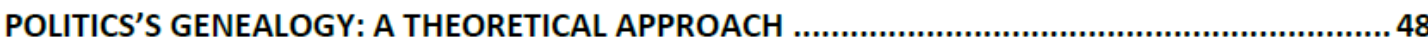

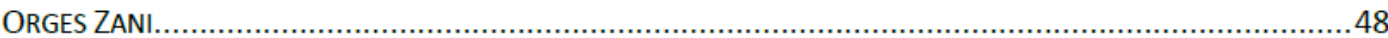

DIFFICULTIES THAT STUDENT ENCOUNTER WHEN LEARNING THE CULTURE OF TARGET

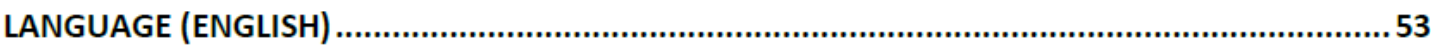

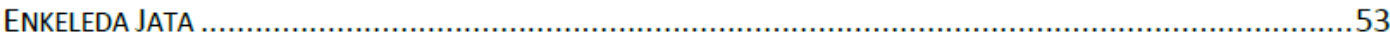

THE TECHNIQUES USED FOR READING COMPREHENSION INSTRUCTION, CASE STUDY ALBANIA.

58

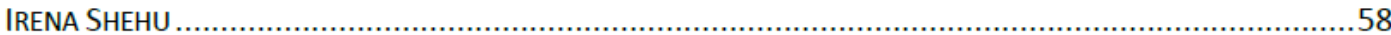

FIGURATIVE TRANSFORMATION OF FREE COMPOUND WORDS INTO ADJECTIVAL PHRASEOLOGICAL UNITS IN THE ALBANIAN AND ENGLISH LANGUAGE TO BE ACQUIRED FROM THE STUDENTS. 
DR. LEDIANA BESHAJ

PROMOTING HABITS OF REFLECTION AND SELF-EFFICACY THROUGH GUIDED REFLECTION IN AN EFL WRITING COURSE 78

RUDINA GULEKER 78

PARENT-CHILD INTERACTION IN LANGUAGE ACQUISITION AND PERSONALITY DEVELOPMENT OF YOUNG CHILDREN IN MONOLINGUAL AND BILINGUAL FAMILIES ........................................... 82

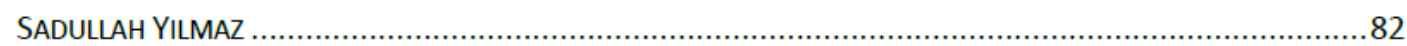

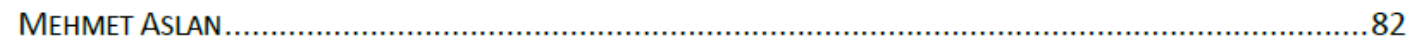

ALBANIANS IN PRESEVO VALLEY AND THEIR NATIONAL RIGHTS ..........................................90

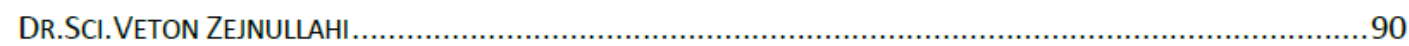

MYTH AND ANTIMYTH IN THE FICTIONS OF SOCIALIST REALISM IN ALBANIA .............................96

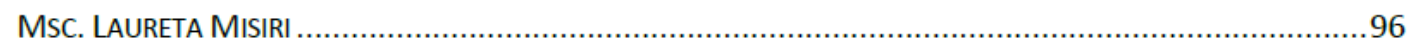

THE REAL POWER OF THE SOCIAL MEDIA, THE INTERPRETATION OF THE ESTABLISHING COMMUNICATION WAYS, AS ILLUSTRATED BY THE TURKISH ASSISTANCE DURING THE KOSOVO

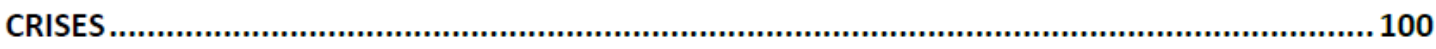

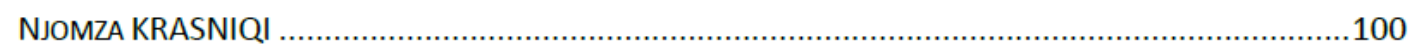

THE CONTROL OF INFORMATION IN TRADITIONAL MEDIA THROUGH THE SOCIAL ONES .......107

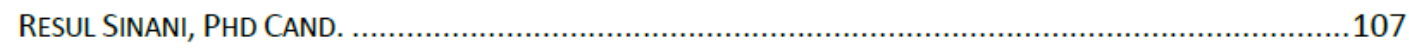

FRIENDSHIP, DREAMING AND INVENTION AS A PATH TO MATURATION SHOWN IN THE NOVEL

"CLEVER INVENTORS" BY VIOLETA MARTINOVSKA ..................................................................113

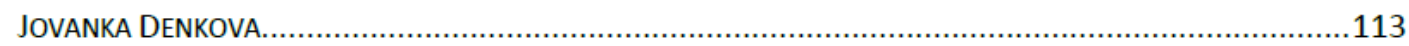




\title{
Friendship, Dreaming and Invention as a path to Maturation shown in the novel "Clever Inventors" by Violeta Martinovska
}

\author{
Jovanka Denkova \\ Faculty of Philology, \\ Goce Delchev University, \\ Shtip, Macedonia \\ jovanka.denkova@ugd.edu.mk
}

\begin{abstract}
In this paper is processed topic of adolescence shown in the novel 'Clever inventors' time as a transition from one stage of life, a time of research, impatience, ingenuity, curiosity, looking for something new and unique so far unknown to the children of Magyar neighborhood. Adolescence is the period when the young man begins to mature in their own way, live in their own world, each of them individually accept this time and knows how to passes through it. Amongst novel "Umnite izmisluvaci" ("Smart inventors") by Violeta Martinovska childhood and adolescence are nailed together, they are complementing and rely. Childhood in persons does not stop, it takes until they dream and feel like children. Children's spirit is present everywhere in the novel, child temperament, but the child maturity is one that leaves a great impression on the reader. In no case is emphasized children's game that will leave irreparable damage, inventors really succeed with their imagination and restless spirit to reach out to the reader and to present the real environment in which they live.
\end{abstract}

Key words: adolescence, curiosity, imagination, maturity.

\section{INTRODUCTION}

Many adolescent readers are drawn to fiction that is set in the present. They can often identify with characters and events in contemporary fiction, as they and their experiences are easily recognizable and somehow familiar, despite the differences of place or culture or values that underpin the story (Glenn, George, 2012: 44). ${ }^{1}$ Through contemporary fiction, we witness models for our own lives and live vicariously through others, learning from their mistakes without necessarily having to make them on our own. The recognizable realities of contemporary novels offer readers "a better chance to be happy" by helping them develop "realistic expectations" and "know both the bad and the good about the society in which they live" (Donelson, Nilsen, 2004: 117). ${ }^{2}$ Rosenblatt focuses his attention on the adolescent as a reader of this literary genre, linking it to the need for the reader to enter into the experience of others, to feel the beauty and intensity of what the world offers. All that Rosenblatt connects with human need to connect and identify. This is where she sees the positive side of adolescent literature or research experiences of others through literature, can directly help in empowerment and building self-confidence. Linking with similar experiences can help adolescent-reader to feel less lonely or to serve as a guide, or to serve as a guide through his own experiences, and to explore human relationships, issues related to morality or social

\footnotetext{
${ }^{1}$ Wendy J. Glenn, Marshall A. George, Looking into and beyond Time and Place: The Timeless Potential of YA Lit in a Time of Limited Opportunity, The ALAN Review, Fall 2012, p.44

${ }^{2}$ Donelson, K., \& Nilsen, A. (2004). Literature for today's young adults (7th ed.). New York, NY: Allyn \& Bacon
} 
expectations (Rozenblatt, 1938). ${ }^{3}$ We may completely agree with the position of Rosenblatt, the need for young people to organize themselves into groups and it is confirmed by research of Gisela Konopka from Center for research and development of young people at the University of Minnesota developed the concept of normal adolescence in 1973. From her research resulting five key concepts and features six adolescence. The five concepts of adolescence "experience of physical sexual maturity", "experience of withdrawal from the protection of adults", "awareness of themselves in interaction with others," "reassessment of values" and "experimentation". According to her, adolescence characteristics are: "uncertainty", "deep sense of loneliness", and "a high degree of psychological vulnerability, "change of mood", "strong need to be part of the group" and "need to be emotional and in the mood for a fight" (Konopka, 1973). ${ }^{4}$

\section{THE NOVEL “UMNITE IZMISLUVACI” BY VIOLETA MARTINOVSKA - PICTURE OF ONE MUTUAL YOUTH}

The novel „Umnite izmisluvaci“ ("Smart inventors") talks about life in Magyar neighborhood, the ratio of children to adults and vice versa, everyday coexistence build common, school desks that teach children to mature faster and taking place in the adult world. In the novel "Umnite izmisluvaci"5 central place are main characters - Magyar (Tony), Zlatokosa, Caki Brave and Vice Bike that during their early childhood - adolescence going through interesting times on the streets of Magyar neighborhood.

They invent their first names, speak and tell of peaceful place called Magyar neighborhood, the railway station where constantly go, meadows that surround them, compare their personality with many similarities of everyday life, express the features of each child. Magyar is the only boy in the company which constantly praises and expresses his manhood before the three girls and be the leader, according to his gender. One definition of Gender Role according to the Oxford Dictionary of Psychology is, ,a set of behavior patterns, attitudes and personality characteristics stereotypically perceived as masculine or feminine within a culture“ (Gender Role 2009). ${ }^{6}$

There are many theories concerning gender roles and many common assumptions about them as well. One popular theory developed by Bem (1981) is referred to as Gender Schema Theory. Gender Schema Theory asserts that children learn gender roles from society and that the sex roles they learn from society they then mold into gender schemas that they attribute to themselves (Bem, 1981, p. 355). ${ }^{7}$

\footnotetext{
${ }^{3}$ Luis, Rozenblatt, Literature as Exploration, New York: NY, D., Appleton Century Company, 1938.

${ }^{4}$ Konopka, G (1973). Requirements for Healthy Development of Adolescent Youth. Adolescence, 8, (31), https://www.adph.org/ALPHTN/assets/043009_req.pdf

${ }^{5}$ Violeta Martinovska is born (1970), in Skopje, in Magyar neighborhood. She graduated on Faculty of Philology at the Department of Macedonian and South Slavic literature in Macedonian language at the University ,, St. Cyril and Methodius, Skopje. She worked as a teacher of Macedonian language and literature. Now working at the National and University Library „St. Kliment Ohridski”. She is author of 170 reviews, studies, articles, essays and short stories. One of its most significant and best-known works is ,Smart inventors" novel that depicts child life in Magyar neighborhood and the transition of the child from the period of childhood in adulthood.

${ }^{6}$ Anjaleena Soni, Gender images and identities (de) constructed in the Young Adult English literature in global perspective, Vol.7, 2, 2014, http://www.englishcyber-literature.net/01.pdf, accessed on 09.01.2016.

${ }^{7}$ Christina M. Kimsey. Gender Bias and Stereotypes in Dystopian Young Adult Literature. A Master's Paper for the M.S. in L.S degree. April, 2011. 44 pages. Advisor: Sandra Hughes-Hassell,
} 
The manner in which genders are represented in adolescent literature has the capability to impact young adults' attitudes and perceptions of gender-appropriate behavior in society. As author Mem Fox (1993) states, ,Everything we read...constructs us, makes us who we are, by presenting our image of ourselves as girls and women, as boys and men (Fox, 1993: 84-88). ${ }^{68}$ Without doubt, the impact of the school and literature in the formation of identity among youth is great, especially in forming their views on gender differences. In creating the story, the writers decide which characters and themes have an important place in their cultural awareness, with certain exceptions it is the cultural norm to illuminate action policy unconscious (Jameson, 1981). ${ }^{9}$ Certain authors as Svetlana Tomić (Tomić, 2012: 41) ${ }^{10}$, point to some feminist ${ }^{11}$ and sociological analysis (Burdije 2003; Guillory 1993) ${ }^{12}$ of culture according to which it was determined that there is a link between patriarchal-centric ideology, patriarchal-centric education system and patriarchal-centric canonization which is not so naive. She points out the predominance of the male gender, his powers and knowledge. According Guillory, if through such patriarchal-centric stories in literature passes silently, there is a danger that they can be accepted as inevitable, so the school has a social obligation to give students access to those works which are an important and significant part of their culture (Guillory, 1993: 52). ${ }^{13}$

Young adults may be particularly susceptible to gender portrayals in literature as they work through a stage in life in which they are searching to define themselves. Gender stereotypes in literature can prevent young adults from reaching their full potential as human beings by depriving them of suitable role models and reinforcing age-old gender constraints in society. These stereotypes exist for both genders and are equally dangerous. While girls are portrayed as passive and weak, boys and men are rarely presented as feeling and vulnerable human beings (Jacobs). ${ }^{14}$

Despite their baptized names, they mutually rename each other according to their individual characteristics. So, Victoria, gets her name because she is constantly on her bicycle, Sonja - because she is brave and fast, Tony- according to neighborhood of origin, and Zlatokosaaccording to her hair. Precisely through their naming can be seen the gender approach in the novel, that equality between boys and girls: ,And you, Sonja, we will call you CAKI BRAVEONE "... You are brave like a Turk and you beat beter than male. You're especially proud of the feminine "(10). Another example that shows equal gender access is when the boy Nikola offers Vice Bike to be his sister, and he to be a brother to her, of course secretly, until they get a real sister and

https://cdr.lib.unc.edu/indexablecontent/uuid:34a7dafa-1bb9-48ad-8bb0-6d3571706522, accessed on 09.01 .2016

${ }^{8}$ Fox, Mem. "Men Who Weep, Boys Who Dance: The Gender Agenda Between the Lines in Children's

Literature." Language Arts 70 (1993): 84-88.

${ }^{9}$ Frederic Jameson, The Political Unconscious: Narrative as a Socially Symbolic Act, Ithaca/New York, Cornell University Press, 1981.

${ }^{10}$ Svetlana Tomić, Price srpskih klasika Laze K. Lazarevića i Ive Andrića: dva primera patrijarhalno-stereotipnog konstruisanja likova devojcica, Detinjstvo, Novi Sad, 2, 2012, 41.

${ }^{11}$ Warthol, R. Robin\&Herndl Price, Diane (1997), Feminisms: An Anthology of Literary Theory and Criticism, New Brunswick, New Jersey, Rutgers University Press.

${ }_{12}$ Pjer Burdije, Pravila umetnosti, Geneza i struktura pola književnosti, Novi Sad, Svetovi, 2003; John Guillory, Cultural capital: The problem of Literary Canon Formation, Chicago and London, The University of Chicago Press, 1993.

${ }^{13}$ John Guillory, Cultural capital: The problem of Literary Canon Formation, Chicago and London, The University of Chicago Press, 1993.

${ }^{14}$ Kathryn Jacobs, Gender issues in young adult literature, https://scholarworks.iupui.edu/bitstream/handle/1805/1335/Gender\%20Issues\%20in\%20Young\%20Adult\%20Litera ture.pdf? sequence=1, accessed on 09.01.2016 
brother: „That day I felt strange. Suddenly I had a brother. Nichola is now the most important name in class "(50). Another point in this equal gender aproach between the characters is one of their everyday children's games, playing with marbles, which are usually considered exclusively "man's game" because the girls play it very rarely: , I always win with marbles ... I was very precise with marbles "(28); "I had no equal in the marbles in the neighborhood. I've no idea how I could be so precise with them (166-167)“. In this context, it is interesting to note that Vice Bike gives to us about how her parents understand her obsession with marbles. In fact, there was a patriarchal relationship by her mother, which a dim view of it, unlike her father: "My mother was very angry because of the marbles... So I had to hide them somewhere. My father did not scold me about them and gave me some more homegrown marbles "(166-167). Finally, the last point in which is evident gender approach among the children of the street, is the moment when they say all the funny names:

-There are many funny names ... Ljuta, Limonka ... Rose, Loza ... - Magyar was grinned. - You are saying only female names. There are also funny male names. For example, Herby, Flower, Pearl, Easterner - respond Caki "(180-181).

Contrary ridicule tones of Magyar to "funny" female names with floral overtones, as a feature of the feminine principle / gender, Caki opposite him "male funny" names, also with floral overtones, and in some way feminizes them.

Besides mutual coexistence which children built, they respect adults too, the bus driver uncle Krume was so good that they constantly impound the bus and drove to the end of the street, and they eagerly watching for the moment when he will pass with the bus.

Adolescence presented in the novel is continuously connected with the contradictory and sudden events experienced by children in Magyar neighborhood. Although adolescence is a period of curiosity, yet the children of the neighborhood gives the possibility of making positive changes to overcome the difficulties and problems and to establish a balance between the identity and integrity of each child.

Adolescence as such a process, to the young from Madzar maalo allows separation from their parents, forming and gaining its own identity and its own voice in society. If Magyar, Zlatokosa, Vice and Caki were brought up in a same family then the probability that there will be no difference between them is great. Like four characters, they represent the four different areas and ways of education, but as an entity they function very interesting which is characteristic of adolescence as a transition from childhood to maturity.

The narrative is organized in a certain past (Perfect and imperfect) time. The narrator (Victoria - Vice bicycle) through reminiscences tells of events which occurred in childhood. ${ }^{15} \mathrm{In}$ the novel is described only one stage through going Magyar, Zlatokosa, Caki and Vice - this is the stage of early childhood maturity which can later be called the children's immaturity. The characters of each child going through the process of upgrading, conscious activity and consciously changing of the characteristics they own. Each of these street children from the neighborhood come with their respective domestic education that at point can't hide. They apparently did not differ, however, in permanent childhood conversations they reveal more and more. The secondary characteristics of Magyar, Zlatokosa, Caki and Vice arise in physical and psychological characteristics and they fallow them up to the moment when the changing of social relations between boy and girls starts. Magyar desire to increase his circle of friendship is the main reason that causes the adolescent to start an argument with Zlatche because of her belief that it

${ }^{15}$ Ranko Mladenoski, Cekajki ja egzegezata, Sovremenost, Skopje, 2005, p.255. 
can't also remain as good friends with them if there is anyone who would he consider as best comrade. At that point the Magyar occurs desire to increase the circle of friends and thus will be manifested by an increase in both the community and the environment in which he lives. The adolescent period in children from Magyar neighborhood is conditioned by the environment, the climate, the culture, customs and upbringing. Umnite izmisluvaci are constantly occurring and doubt whether that really what to aspire adults is the correct thing in life? They manifest doubts to parents when they compare their views with their, and coming to the conclusion that the attitudes of parents are considered "unfashionable," "wrong," "ridiculous" and based on that, the children from Madzhar maalo experiencing self-confirmation and they note themselves in front of the others. In no case they do not allow the damage to their own ego by children from Aerodrom nor from anyone else who is close to big for them indispensable Magyar maalo.

The lives of children in Magyar neighborhood takes place, according to their rules. Living outside of the world of adults, they with their insufficient adulthood constantly reveal wise and ingenious solutions to problems of everyday life. From the very beginning of the novel reveals the relationship between children, their love, admiration of personal actions and common children's games which seem to stop seemingly.

The period wich 'inventors' are going through is a period of maturation and building individual person, it is the period which every person in life is going through and it's called adolescent period. Building their own world they set their barrier between the adult world and their own childhood. Everything starts from the games of main characters Magyar, Zlatokosa, Caki and Vice Bike that never stop their game because they think that if they stop the game then you are an adult, so the game must constantly reign in the hearts of each of us. Who does not want to become an adult should not be interrupt game and calm the mischievous children's spirit. Here we found justified claim of the German theorist Johan Huizing, which he offered in his work Homo Ludens. According to him, "the game is a voluntary activity that takes place within some stipulated time and spatial boundaries". Huizing understands the game as "serious and frivolous activity, although he calls it called foolish, but always in relation to wisdom" (Huising, 1970: 44). ${ }^{16}$ The game is the same kind of art that expresses the joy of imaginary life. Well, in the case of this novel, we can safely say that the boundaries within which the game takes place, the invention of the children of Magyar neighborhood, is precisely their space, the space of the street, space of childhood. Inventing names, inventing brothers and sisters, is just one way the young man by using his imagination tries to avoid the pitfalls of life, to create a different world, in which their wishes are easily achievable (Prelević, 1978:96-97). ${ }^{17}$

Despite the different relationship between each of the characters with their parents, yet parents are the ones who constantly admired the drawings that children placed in frames, and later hung on the wall. The drawings represent a very important element that too simply fail to show children's imagination in adolescence and thereby reveal many hidden children's wishes.

Adolescence brings nostalgic feelings, feelings of loneliness, emptiness and sadness in soul. This novel is best displayed in the part when everyone talks about his brothers and sisters, but Nichola and Vice are silent and mourn because they are lonely and do not live in a family with many children. Vice thinks that all difficulties and hardships can be overcome easier when you're not alone, but life is sometimes strange and it is difficult to understand destiny. Sorrow awakens the imagination and Vice and Nichola they both agree to be brother and sister This section clearly displays adolescence children are going through, because adults in the same situation would not

\footnotetext{
${ }^{16}$ Johan Huising, Homo ludens, Marica Hrvatska, Zagreb, 1970, p.44.

${ }^{17}$ Rade Prelevič, Poetika dečje književnosti, Prva književna komuna, Mostar, 1978, str.96-97.
} 
have acted the way Vice and Nichola acts.

Adolescence in Magyar, Zlatokosa, Vice and Caki can't be forwarded to the physical changes they experience over the course of this period, but it consists in their children's heads, psychic power, motivation and endurance. They are making fun of each other, criticizing each other's, wit in the invention of new games and competitions, it is in order to make the day more interesting, and also the child's life more fun.

Despite the fact that they are still children, they perceive friendship in a special way. Friend for them is sacred, the most important person in their lives, they consider that there is no real sadness and happiness if we don't have a friend with whom to share. Understanding that friends are irreplaceable make smart minds of inventors even smarter and more valuable in adolescence child development and action: "The friends will went out like flowers if they are not regularly pour water to survive." 18 . The Fellowship is a set of persons of the same or opposite sex, whose collective behavior is determined by internal voluntarily accepted rules. The rules of the group often emphasize a moral norm, which at the time was current in society and group endeavors that rule strictly respected. The group can be with differentiated or undifferentiated gender, created with clearly defined purpose, with a simple structure and strong hierarchy with defined gender roles (Krstić 1988:120). ${ }^{19}$

From the very beginning their natural and realistic attitude towards our environment reflects the child's nature and child temperament. The period through which they pass is a period of ignorance that they replace by inventing such a favorite thing they most want to do. About invention they constantly say something that comes, naturally, and thereby also build their world in which everyone can't enter.

The period through which children from Magyar neighborhood pass is quite strange, they constantly monitor their adult life habits, behavior, dress and in many situations they try to look like adults, while inadvertently reveal their curiosity to learn about the world adults.

The happiness of the young adults in the novel consists of little things that make their life somehow perfect. Making cakes for Magyar, Zlatokosa, Vice and Caki shows the most interesting moments of the adolescent phase through which they pass from the beginning until the end of the novel. This part presents the child's attention, patience which children can express in quite different way from adults without cause and reason they constantly invent birthdays in order to feel pleasure while.

Especially important and interesting moments are when they have something to celebrate in their homes. In Magyar neighborhood children repeatedly expressed their happiness for the holidays, but one of the most beautiful days is that Aprilijadata which Magyar, Zlatokosa, Vice and Caki will eagerly await. They rejoice because the celebration of the April Fool's day, lots of laughter and fun, while not punishing anything you would do. For them first April is a great day because anyone can be what he desires. Henri Bergson says that humor "is a gift from the heart, he is a life jacket or swimming across the river of life" (Bergson, 1968). ${ }^{20}$ Or, as Aleksandar Vuco sais: "In the children's world there is a special, authentic humor. In young beings that humor is a defense of the injuries they inflicted outside world causes to tham. It means it is necessary as a lightning rod for their difficulties (Vuco, 1989:11). ${ }^{21}$ In fact, humor, play, invention, imagination, hedonism, it

\footnotetext{
${ }^{18}$ Martinovska, Violeta, Umnite izmisluvaci, Kultura, Skopje, 2002.

${ }^{19}$ Dragan Krstić, Psiholoski recnik, Beograd, Vuk Karaђić, 1988.

${ }^{20}$ Anri Bergson, Smijeh, Znanje, Zagreb, 1968.

${ }^{21}$ Aleksandar Vuco, Razmisljanje o literaturi za decu, Ptica u letu, Citanka za vaspitace medicinskih skola, Zavod za uđbenike, Beograd, 1989, p.11.
} 
is an integral part of poetics of literature for children and young people, so it should not be surprising that all these elements are present in this novel for children who cross the threshold of childhood (Kitanov, Marjanovik, 2007: 49-69). ${ }^{22}$

Significant place in adolescence that are going through Magyar, Zlatokosa, Caki and Vice, occupy songs they themselves invent, the tongue twisters that have exceptional fun and pedagogical function. Wit as an important element of early childhood development, in the novel is described by the invention of games by "Smart inventors", names of games and prizes awarded in order to attract more attention.

The tongue twisters in ,Smart inventors" beside purpose to cause of laughter contributes to the streamlining of the children from the neighborhood how to speak properly and develop their speech although during the game they do not sense for this type of pedagogical function.

In the process of building a child's personality and the children's character Magyar, Zlatokosa, Caki and Vice constantly invent new songs in which they sing about their favorite meal. Here's favorite food of Zlatche in playful song:

Hamburger, hamburger you're sweet sandwich

I will gulp you, I will gulp you down in the blink of an eye.

Momy bought you, Momy bought you

when I was in town.

In your odor in your odor

my belly cries. ${ }^{23}$

Although it is not as adept at composing verses, Magyar still trying to think of something that would smile everyone. In this case is reflected persistence that govern child, failure does not bring disappointment, rather it is the motive that the child carries within and outside the impetus is the success of others. Magyar with the help of Zlatche, invents the end of the song for his favorite meal:

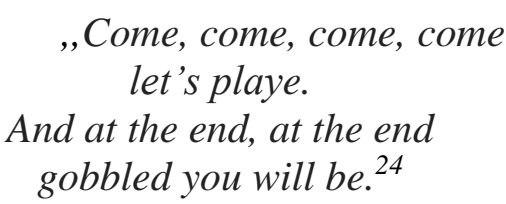

How truly smart are inventors of Magyar neighborhood in this children period speaks and organization of competitions in which other than songs, they simply invented the names of their favorite sandwiches and those prepared during the competition:

\author{
Stingy sandwich \\ pause sandwich \\ All sandwich home \\ a pleasant sandwich \\ Slim salami sandwich \\ Shofer sandwich \\ What sandwich was found
}

\footnotetext{
22 Blaze Kitanov, Voja Marjanovic. Literatura za deca i mladi, I, Stip: Faculty od Pedagogy “Goce Delcev”, 2007.

${ }^{23}$ Violeta Martinovska, Umnite izmisluvaci, Kultura, Skopje, 2002.

${ }^{24}$ Violeta Martinovska, Umnite izmisluvaci, Kultura, Skopje, 2002.
} 


\section{imps sandwich \\ Summer holiday sandwich \\ Urnebes sandwich \\ Zanzibar sandwich \\ Expensive butter sandwich \\ Feed me sandwich \\ Thick oak shade sandwich \\ King Kong sandwich \\ Healthy sandwich. ${ }^{25}$}

All these names of the sandwiches that were cooked by children in the Magyar neighborhood testify for children's creativity and ingenuity that is most characteristic of adolescence in the life of a child.

Adolescence at Magyar, Zlatokosa, Caki and Vice is assessed through everyday fables provided by them, they are not feature with psychological changes in the novel, their children view is able to capture only child carefree life filled with many interesting, games, laughter, inventing that day by day change only the universe of a child.

Dreams and stories occupy an important place in adolescence. Children perceive dreams differently than adults, they envision dreams as part of their lives, something that really is, and something that happened and left deep traces in the child's life. Dreams, according to Vice, are sometimes ugly, but we can never escape from dreams.

Of course, as is typical for an adolescent novel, it is not abandoned period of falling in love for whom curiosity and desire to find out more is highest among adolescents. First infatuation never forgets, it remembers for a lifetime, then the children are different, they change, they feel they are very important and then the whole world is in their subconscious property.

The girls were in love with Vlado and boys in Christina, notebooks were constantly inscribed with the names of children. Those who were most enamored characterized as persons who possess great care, full of surprise and haughty behavior. Sided love for the children of Magyar neighborhood is not love, they imagine love in a different way - mutual care, respect and attention. Consideration of all corners and sides of the psyche and the perception of an individual person is an important element of mutual acquaintance among children. Love between a boy and girl in the adolescent period, does not exist outside the boundaries of knowledge and mutual existence in close correlation.

Each child manages to express his wishes, requests and his unfulfilled dreams. Quartet which is constantly together describes their love for pets. They monitor the secret relationship between humans and animals - coming to different conclusions that people who do not like animals, do not want any people. Talks on pets and unusual desire of Vice to have a horse as a pet is constantly causing laughter in others.

Matches organized in Magyar neighborhood represent the tip of the all-sense as children call them. Despite the imagined reality children are fighting as real, honest, no hassle and insinuations. They hate injustices just like they hate F's in school and they celebrate victory with joy as they celebrate A's in school desks.

Standing courage in fighting kids from Aerodrom, they receive through determination to protect their children's ego and never experience defeat. But despite all efforts fear is horrible thing for

\footnotetext{
${ }^{25}$ Violeta Martinovska, Umnite izmisluvaci, Kultura, Skopje, 2002.
} 
children they do not like, and unfortunately each of them possesses.

The desire to succeed and not to give up, Magyar consistently leads through life, he opposes the defeat in sports games which are organized, never recognizes the victory of Aerodrom's children, always able to make the main on the street and number one in Magyar neighborhood.

Against his assertiveness are Zlatche beliefs and her thinking about everything that makes Magyar and constantly enraged and advise him. Magyar is represented in the pursuit of maturity and despite his desire he does not manages to perfect it to the end, because adulthood is a period characterized by the acceptance of the conditions of life, and on such a thing he was not ready because he is always for changes occurring, wants to experience something new, unknown and unusual for children's everyday life Magyar neighborhood.

In moments of clever fables by innovators the most amazing are those who speak for the unborn children, actually all the children in the neighborhood Magyar speaking eagerly expressing their great desires. An important moment of adolescent life is the choice of future profession of the person, so smart inventors are constantly talking about their future careers as favorite topic of conversation.

Despite the fact that adults do not pay enough attention in this regard, however, the children are the ones who really know everything. Their smart heads constantly seeking, and give precise answers to difficult and different questions.

Through their ideas to make something original, they really represent the child - adolescent nature that is very different from that of adults. The adults who do not have dreams, they do not know how to dream, they see the world through the prism of seriousness, accelerated pace which in more cases may affect an adolescent who is in the process of developing and building its own individual personality.

For adolescents from Magyar neighborhood everything that surrounds them is new, for the first time in their lives they face a challenge that brings destiny. Although it is a small and unimportant issues and child care, however Magyar, Zlatokosa, Vice and Caki manage to overcome every moment that lies ahead. Life for them is unknown, but they do not feel fear, rather they learn, invent and constantly have something to talk about.

Summer break for kids from Madzhar maalo is the greatest happiness as well as for all other children in this period of life. It is the greatest joy and eventually for all the pain and suffering in school Magyar, Zlatokosa, Vice and Caki, then children's hearts feel free from over-loads of books, and it is time for the kingdom of the game, freedom and joy. Many of the children do not know what they want, but Vice always have one and only wish that she hides deep inside, the desire for a brother.

She is a person who at the time of adolescent development needs someone who's really close, who would tell him everything, all her sufferings and tribulations. Despite trying to look with the eyes of an adolescent it can't succeed, because children are the ones who can best explain and express what we experience deep down, mind vs. heart, or heart - mind.

The sadness of children is greatest when they are sick, Vice with his friends from the Magyar neighborhood constantly talking about the ratio of adults to children when they are sick. Children's little heads can be bent and uninterested in childish games but despite the mischievous spirit children managed. The desire is continually present in those moments is the strongest desire sooner to heal.

The end of the novel is the description of a future profession of Magyar, Zlatokosa, Vice and Caki, while the author himself remembers his own childhood, and comes to the conclusion that child light is the one that saves the world. Zlatokosa adolescence is manifested by greater maturity unlike 
other children in the neighborhood. She is constantly on the side of severity, always said that they should be careful not to fall into some trouble, and often opposes the crazy ideas of Magyar who thinks that they are okay.

She opposes Magyar when they talk about math assignments, arguing that his sister will no permanent solve the tasks and problems around that subject. The transition of childhood into maturity in the case of Zlatche is presented as faze of already past adolescence, but because of her environment she is also a part of everyday clique from Madzhar maalo and everyday children's antics.

\section{CLOSING REMARKS}

Adolescence is a period of transition from early childhood to maturity. From the root of the word it derives its meaning of maturation and development of the individual personality with their own qualities and abilities to act in society.

Adolescence in „Smart inventors" is shown from the very beginning of the novel through life in Magyar neighborhood, schools and children's games that are part of everyday life of the main characters Magyar, Zlatokosa, Vice and Caki.

Term "maturity" is quite broad and includes intellectual, social and emotional readiness for acceptance and improvement of living conditions, but for it Zlatche is not ready despite the characteristics of a mature person. Early adolescence in children from Magyar neighborhood is time that they spend together, most of the advantage of each recharge children's play and inventing that are part of everyday life.

Needs, interests, will, attitudes and ideals that characterize children are the main drivers of each person is exposed to from early childhood until the transition to adulthood. Adolescence for Magyar, Zlatokosa, Vice and Caki mostly depends on the environment, daily activities and pursue temperament who owns each of the children. Different perceptions of children as exemplified by Zlatche and Magyar depends not only on them both as individuals, it is a "consequence" of a lengthy process that the environment in which they still in its very birth act and live.

Adolescence is a period through which person passes through a number of stresses and many effects of the external environment and in the case of Zlatche, she feels changes as a result of external environment, changes in emotional development and understanding of the children's world in which she lives.

The dynamic period of Magyar, Zlatokosa, Vice and Caki is actually a period of intellectual, social and emotional readiness for acceptance and improvement of living conditions. Although adolescence is considered the end of the training of a sufficiently mature, yet at the end of this period lies the beginning of a new stage and a new experience that continues to change the person until the end of her life.

Desire of Magyar, Zlatokosa, Vice and Caki to protect themselves against social prejudices about children's thinking and action imposes a greater number of features that can be a problem, both for themselves and for the environment in which children live.

\section{REFERENCES}

1. Bergson, A. (1968). Smijeh, Znanje, Zagreb. 
2. Burdije, P. (2003). Pravila umetnosti, Geneza i struktura pola književnosti, Novi Sad, Svetovi.

3. Donelson, K., \& Nilsen, A. (2004). Literature for today's young adults (7th ed.). New York, NY: Allyn \& Bacon

4. Fox, M. (1993). Men Who Weep, Boys Who Dance: The Gender Agenda Between the Lines in Children's

5. Glenn, J. W., George, M.A. (2012). Looking into and beyond Time and Place: The Timeless Potential of YA Lit in a Time of Limited Opportunity, The ALAN Review, p.44

6. Guillory, J. (1993). Cultural capital: The problem of Literary Canon Formation, Chicago and London, The University of Chicago Press.

7. Huising, J. (1970). Homo ludens, Marica Hrvatska, Zagreb, p.44.

8. Jacobs, K. Gender issues in young adult literature, https://scholarworks.iupui.edu/bitstream/handle/1805/1335/Gender\%20Issues\%20in\%20Young\%20Adult $\%$ 20Literature.pdf? sequence $=1$, accessed on 09.01.2016

9. Jameson, F. (1981).The Political Unconscious: Narrative as a Socially Symbolic Act, Ithaca/New York, Cornell University Press.

10. Kimsey, C.M. (2011). Gender Bias and Stereotypes in Dystopian Young Adult Literature. A Master's Paper for the M.S. in L.S degree. 44 pages. Advisor: Sandra Hughes-Hassell, https://cdr.lib.unc.edu/indexablecontent/uuid:34a7dafa-1bb9-48ad-8bb0-6d3571706522, accessed on 09.01.2016

11. Kitanov, B., Marjanovic, V. (2007). Literatura za deca i mladi, I, Stip: Faculty od Pedagogy "Goce Delcev".

12. Konopka, G (1973). Requirements for Healthy Development of Adolescent Youth. Adolescence, 8, (31), https://www.adph.org/ALPHTN/assets/043009_req.pdf

13. Krstić, D. (1988). Psiholoski recnik, Beograd, Vuk Karałić.

14. Literature." Language Arts 70, p. 84-88.

15. Martinovska, V. (2002). Umnite izmisluvaci, Kultura, Skopje.

16. Mladenoski, R. (2005). Cekajki ja egzegezata, Sovremenost, Skopje, p.255.

17. Prelevič, R. (1978). Poetika dečje književnosti, Prva književna komuna, Mostar, p.96-97.

18. Rozenblatt, L. (1938). Literature as Exploration, New York: NY, D., Appleton Century Company.

19. Soni, A. (2014). Gender images and identities (de) constructed in the Young Adult English literature in global perspective, Vol.7, 2, http://www.englishcyber-literature.net/01.pdf, accessed on 09.01.2016.

20. Tomić, S. (2012). Price srpskih klasika Laze K. Lazarevića i Ive Andrića: dva primera patrijarhalnostereotipnog konstruisanja likova devojcica, Detinjstvo, Novi Sad, 2, p. 41.

21. Vuco, A. (1989). Razmisljanje o literaturi za decu, Ptica u letu, Citanka za vaspitace medicinskih skola, Zavod za uđbenike, Beograd, p.11.

22. Warthol, R. Robin\&Herndl Price, D. (1997), Feminisms: An Anthology of Literary Theory and Criticism, New Brunswick, New Jersey, Rutgers University Press. 